\title{
Bench-scale calcination and sintering of a goethite iron ore sample
}

\author{
M.S.S. Silva ${ }^{\text {a }}$, M.M.F. Lima ${ }^{\text {b }}$, L.M. Graça ${ }^{\text {c }}$, R.M.F. Lima ${ }^{\text {a,* }}$ \\ a Department of Mining Engineering, Federal University of Ouro Preto, Campus Morro do Cruzeiro, CEP: 35400-000, Ouro Preto, Minas Gerais, Brazil

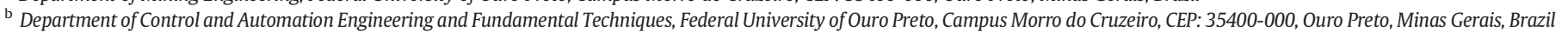 \\ c School of Mines, Federal University of Ouro Preto, Campus Morro do Cruzeiro, CEP: 35400-000, Ouro Preto, Minas Gerais, Brazil
}

\section{A R T I C L E I N F O}

\section{Article history:}

Received 16 March 2015

Received in revised form 16 November 2015

Accepted 31 March 2016

Available online 12 April 2016

\section{Keywords:}

Iron ore

Goethite

Hematite

Calcination

Sintering

\begin{abstract}
A B S T R A C T
This work presents the results of bench calcination and sintering studies conducted on an iron ore sample from Iron Quadrangle, Brazil with high goethite content. The natural samples and the products of calcination and sintering were characterised by inductively coupled plasma optical emission spectroscopy (OES/ICP), X-ray spectrometry and gravimetric methods. Optical microscopy, X-ray diffraction (XRD) and scanning electron microscopy with energy-dispersive X-ray spectroscopy (SEM/EDS) were used to identify the phases in the studied samples. Density, specific surface area, specific pore volume and pore diameter were determined through gas pycnometry. All of the natural sinter feed samples had a Fe grade $>64 \%$ and a very high phosphorus grade $(\sim 0.17 \%)$. After calcination, a 3.1-3.4\% increase was observed in the Fe grade compared to that of the natural sinter feed samples. The average Fe grade of the sintered samples was 59.1\%. The identified phases with XRD in the raw materials were hematite and goethite. In the calcined samples, only hematite was identified because of the thermal decomposition of goethite. The density, specific surface area, specific pore volume and pore diameter of the calcined samples increased compared to those of the natural sinter feed samples. Hematite, brownmillerite, anorthite, and gehlenite were identified in the sintered samples. The sites for phosphorus occurrence were calcium silicates and apatite. The sintered samples exhibited specific surface areas lower than those of the calcined samples. This result was ascribed to the destruction of the pore structure by the sintering process. No relationship between the proportions of nucleate, intermediate and agglomerate particles used in mixture of sinter tests with the results of microtumbler was identified.
\end{abstract}

(c) 2016 Published by Elsevier B.V.

\section{Introduction}

The total world resources of iron ore (indicated + inferred) are 170 billion tonnes. Approximately $12 \%$ of these resources, with an average Fe grade of 50.3\%, are located in Brazil and are distributed among the following states: Minas Gerais - 70\% (46.9\% Fe), Mato Grosso do Sul $-15.3 \%$ (55.4\% Fe), Pará - 13.1\% (64.8\% Fe) and others - 1.6\% (Jesus, 2013).

More than $90 \%$ of the total world's iron ore production is used in the steel industry (blast furnace and direct reduction) (Wolff, 2009). Iron ore with a Fe grade less than $64.0 \%$, such as the actual ores of Minas Gerais and Mato Grosso do Sul, must be concentrated to achieve satisfactory specifications. The choice of beneficiation route for a specific iron ore depends on its mineralogical composition, $\mathrm{Fe}$ and $\mathrm{SiO}_{2}$ grades and size distribution (Araujo et al., 2003; Al-Wakeel and El-Rahman, 2006).

\footnotetext{
* Corresponding author at: Departamento de Engenharia de Minas, Universidade, Federal de Ouro Preto, Campus Universitário, Morro do Cruzeiro, S/N, CEP: 35400-000, Ouro Preto, MG, Brazil.

E-mail address: rosa@demin.ufop.br (R.M.F. Lima).
}

Most of the iron ores from Iron Quadrangle, Brazil are related to Proterozoic banded iron formations (BIFs) of the Cauê Formation (Carlos et al., 2014). The mineralogy of these ores is basically constituted by quartz and iron oxide minerals. In high-grade iron ores, hematite is the main iron mineral. The iron ore deposits of Iron Quadrangle were subjected at least to two metamorphism and deformation events. The metamorphic and deformation intensity increase from west to east and from south to north in the region. These processes beyond the supergene processes were the main factors that changed the texture of the iron ore of this region. In general, the mineral crystal size increases with metamorphism degree (Rosière, 1996; Mendes and Lagoeiro, 2012).

In Brazil, iron ore with a high grade of goethite $(\mathrm{FeOOH})(\mathrm{LOI}>3.5 \%)$, independent of its Fe grade, is considered marginal because goethite causes excessive mud generation in the wet processing step, which is very harmful in flotation (slime coating phenomena) and filtration (blinding) operations. In agglomeration processes (pelletising and sintering), high goethite contents affect both the process control and the final quality of agglomerate (pellet or sinter) (Magalhães et al., 2007; Loo et al., 1994; Yang et al., 2000; Okazaki et al., 2003; Leonel, 2011). 
Loo (2005) reviewed several studies conducted with mix sinter of iron ore containing a high proportion of goethitic (pisolitic) ore; the first of these studies was conducted in Australia in 1990. Although the high porosity and low density of goethitic ore increase its melt volume during sintering, which causes deterioration in granulation and low productivity, among other problems. Operation control (e.g. the addition of more water during granulation, the use of a faster flame front speed than that used in a sinter bed with a denser ore, maintenance of the green bed permeability during the sintering operation and other factors) can provide good performance for a sinter mix with a high proportion of goethite ores.

Detailed technological characterisations (i.e. physical, mineralogical and chemical characterisations) and specific technological experiments such as bench calcination and sintering of Brazilian iron ores with high goethite contents must be conducted to predict the behaviour of such ores in industrial processes. Such predictions would facilitate modifications to the actual beneficiation routes, which could support the rational use of these ores. This information will be very important for increasing the lifetimes of the mines located in the Iron Ore Quadrangle region.

This work presents the results of bench calcination and sintering studies performed with a natural iron ore sample with high goethite content from the Iron Quadrangle, Brazil; the samples contained different proportions of nucleating, intermediate and adherent particles.

\section{Experimental}

\subsection{Materials}

The raw iron ore sample (52 kg) preparation was constituted by comminution by jaw and roll crushers to $-3.36-\mathrm{mm}$ size. This size was determined based on work carried out by Umadevi et al. (2011), who studied the influence of iron ore fines (mean particle size from 1.22 to $3.95 \mathrm{~mm}$ ) on mineralogy, productivity, physical and metallurgical properties of the sinter. The comminuted ore, after being homogenised, was split into sub-samples for the physical, chemical and mineralogical characterisations. For calcination and sintering tests, the sample was size classified by wet sieving in the following fraction sizes: $-3.36+1.182 \mathrm{~mm}$ (nucleating particles), $-1.186+0.209 \mathrm{~mm}$ (intermediate particles) and $-0.209 \mathrm{~mm}$ (adherent particles), which were mixed in different proportions (Table 1 ).

The higher proportion of nucleating particles (70\%) compared to adherent particles (30\%) in SF1 aimed to intensify the granulation of mixture and, consequently, it could directly affect the permeability of bed sintering. The substitution of 15 wt.\% of nucleating particles and adherent particles by intermediate particles, respectively in SF2 and SF3, was based on practise of industrial plant of sintering, which uses the maximum of $15 \mathrm{wt}$.\% intermediary particles. This is done because intermediate particles do not have defined behaviour like nucleating or adherent particles. The higher proportion of adherent particles (70\%) compared to particles nucleating (30\%) in SF4 aimed to assess the main mechanisms of granulation using fine particles in mixture of sintering, which provide the increase in bed of sintering (Silva, 2014).

Table 1

Constitutions of the natural sinter feed samples.

\begin{tabular}{llll}
\hline $\begin{array}{l}\text { Natural sinter } \\
\text { feed sample }\end{array}$ & \multicolumn{2}{l}{ Proportions of particles $($ wt.\%) } \\
\cline { 2 - 4 } & $\begin{array}{l}\text { Nucleating }(-3.36 \\
+1.182 \mathrm{~mm})\end{array}$ & $\begin{array}{l}\text { Intermediate }(-1.182 \\
+0.209 \mathrm{~mm})\end{array}$ & $\begin{array}{l}\text { Adherent } \\
(-0.209 \mathrm{~mm})\end{array}$ \\
\hline 1 & 70 & $\ldots$ & 30 \\
2 & 55 & 15 & 30 \\
3 & 30 & 15 & 55 \\
4 & 30 & $\ldots$ & 70 \\
\hline
\end{tabular}

\section{Table 2}

Chemical composition and ignition loss (LOI) of the samples studied: natural sinter feed $(\mathrm{SF})$, calcined sinter feed $(\mathrm{C})$ and sinter $(\mathrm{S})$.

\begin{tabular}{|c|c|c|c|c|c|}
\hline \multirow[t]{3}{*}{ Chemical composition (wt.\%) } & \multicolumn{5}{|c|}{ Sample } \\
\hline & \multirow[t]{2}{*}{ Type } & \multicolumn{4}{|c|}{ Condition } \\
\hline & & 1 & 2 & 3 & 4 \\
\hline \multirow[t]{3}{*}{$\mathrm{Fe}_{(\mathrm{T})}$} & SF & 64.10 & 64.20 & 64.40 & 64.60 \\
\hline & $\mathrm{C}$ & 67.58 & 67.60 & 67.65 & 67.72 \\
\hline & $\mathrm{S}$ & 58.70 & 58.55 & 59.96 & 59.22 \\
\hline \multirow[t]{2}{*}{$\mathrm{FeO}$} & SF & 0.20 & 0.20 & 0.20 & 0.20 \\
\hline & $\mathrm{S}$ & 0.93 & 0.74 & 0.38 & 0.42 \\
\hline \multirow[t]{3}{*}{$\mathrm{SiO}_{2}$} & SF & 1.34 & 1.39 & 1.36 & 1.29 \\
\hline & $\mathrm{C}$ & 1.26 & 1.36 & 1.36 & 1.19 \\
\hline & $\mathrm{S}$ & 2.02 & 1.40 & 1.41 & 1.26 \\
\hline \multirow[t]{3}{*}{$\mathrm{Al}_{2} \mathrm{O}_{3}$} & SF & 0.72 & 0.73 & 0.76 & 0.77 \\
\hline & $\mathrm{C}$ & 0.84 & 0.83 & 0.94 & 0.92 \\
\hline & $\mathrm{S}$ & 0.89 & 0.74 & 0.88 & 0.82 \\
\hline \multirow[t]{2}{*}{$\mathrm{CaO}$} & SF & 0.04 & 0.04 & 0.03 & 0.03 \\
\hline & $S$ & 12.42 & 12.51 & 11.37 & 12.50 \\
\hline \multirow[t]{3}{*}{$\mathrm{MgO}$} & SF & 0.03 & 0.04 & 0.04 & 0.04 \\
\hline & C & 0.06 & 0.06 & 0.07 & 0.06 \\
\hline & $S$ & 0.15 & 0.18 & 0.15 & 0.15 \\
\hline \multirow[t]{3}{*}{$\mathrm{TiO}_{2}$} & $\mathrm{SF}$ & 0.05 & 0.05 & 0.06 & 0.06 \\
\hline & $\mathrm{C}$ & 0.07 & 0.07 & 0.08 & 0.08 \\
\hline & $\mathrm{S}$ & 0.06 & 0.05 & 0.07 & 0.06 \\
\hline \multirow[t]{3}{*}{$\mathrm{P}$} & SF & 0.17 & 0.17 & 0.16 & 0.16 \\
\hline & $\mathrm{C}$ & 0.17 & 0.17 & 0.17 & 0.15 \\
\hline & $S$ & 0.17 & 0.18 & 0.16 & 0.15 \\
\hline \multirow[t]{3}{*}{ Mn } & SF & 0.06 & 0.06 & 0.06 & 0.06 \\
\hline & $C$ & 0.07 & 0.06 & 0.07 & 0.06 \\
\hline & $S$ & 0.06 & 0.06 & 0.06 & 0.06 \\
\hline LOI & SF & 6.11 & 6.07 & 5.67 & 5.46 \\
\hline
\end{tabular}

\subsection{Methods}

\subsubsection{Calcination and sintering tests}

For calcination tests, approximately $20 \mathrm{~g}$ of each sinter feed sample (SF1, SF2, SF3 and SF4) was placed in an alumina crucible that was previously weighed. The crucible with the sinter feed sample was again weighed and introduced into a furnace (FortLab, model ML 1300).

The run conditions of the calcination tests were as follows: natural atmosphere (air), ramp of $10^{\circ} \mathrm{C} / \mathrm{min}$ from 25 to $700{ }^{\circ} \mathrm{C}$ and an isotherm of $35 \mathrm{~min}$ at $700^{\circ} \mathrm{C}$, as previously used by Silva (2014); the tests were conducted on a TA Instruments model TGA Q50 thermogravimetric analyser. After the calcination process, the crucible with the calcined sample was removed from the furnace and cooled in a normal laboratory environment until it reached room temperature $\left(\sim 25^{\circ} \mathrm{C}\right)$. The crucible was then reweighed to determinate the sample weight loss. This procedure was performed three times for each sinter feed sample to produce samples of sufficient mass for the characterisation (physical, chemical and mineralogical) and sintering tests.

For the sintering tests, the calcined sinter feed samples ( $\mathrm{C} 1, \mathrm{C} 2, \mathrm{C} 3$ and $\mathrm{C} 4$ ) were mixed with lime $(\mathrm{CaO})$ and activated charcoal in the following proportions: $80 \mathrm{wt} . \%$ calcination product, $19.35 \mathrm{wt} . \% \mathrm{CaO}$ and 0.65 wt.\% charcoal. Because of the intrinsic characteristics of this iron ore sample, water was carefully added to the mixture during the granulation step to avoid deformation of the sintering bed (Sakamoto et al., 1993; Sakamoto et al., 1997). The control was done by visual inspection. Then, the granulated mixture (approximately $100 \mathrm{~g}$ ) was placed over a refractory brick and sintered in the same furnace used in the calcination tests. After the sintering process, the samples were cooled in the furnace under natural atmosphere until they reached environmental temperature $\left(\sim 25^{\circ} \mathrm{C}\right)$.

The run conditions for the sintering tests were as follows: $\mathrm{i})$ natural atmosphere (air), ramp of $5{ }^{\circ} \mathrm{C} / \mathrm{min}$ from 25 to $300{ }^{\circ} \mathrm{C}$, isotherm of $10 \mathrm{~min}$ at $300{ }^{\circ} \mathrm{C}$; ii) ramp of $5{ }^{\circ} \mathrm{C} / \mathrm{min}$ to $700{ }^{\circ} \mathrm{C}$, isotherm of $10 \mathrm{~min}$ at $700{ }^{\circ} \mathrm{C}$; iii) ramp of $10{ }^{\circ} \mathrm{C} / \mathrm{min}$ to $1000{ }^{\circ} \mathrm{C}$, isotherm of $10 \mathrm{~min}$ at $1000{ }^{\circ} \mathrm{C}$; iv) ramp of $10{ }^{\circ} \mathrm{C} / \mathrm{min}$ to $1200{ }^{\circ} \mathrm{C}$, isotherm of $10 \mathrm{~min}$ at 
Table 3

Mineral phases present in the studied samples: natural sinter feed (SF), calcined sinter feed $(\mathrm{C})$ and sinter $(\mathrm{S})$.

\begin{tabular}{|c|c|c|c|c|c|}
\hline \multirow[t]{3}{*}{ Mineral phase } & \multicolumn{5}{|c|}{ Sample } \\
\hline & \multirow[t]{2}{*}{ Type } & \multicolumn{4}{|c|}{ Condition } \\
\hline & & 1 & 2 & 3 & 4 \\
\hline \multirow{3}{*}{ Goethite (FeOOH) } & SF & $X$ & $X$ & $X$ & $X$ \\
\hline & $C$ & $\mathrm{~N} / \mathrm{I}$ & $\mathrm{N} / \mathrm{I}$ & $\mathrm{N} / \mathrm{I}$ & $\mathrm{N} / \mathrm{I}$ \\
\hline & $\mathrm{S}$ & $\mathrm{N} / \mathrm{I}$ & $\mathrm{N} / \mathrm{I}$ & $\mathrm{N} / \mathrm{I}$ & $\mathrm{N} / \mathrm{I}$ \\
\hline \multirow[t]{3}{*}{ Hematite $\left(\mathrm{Fe}_{2} \mathrm{O}_{3}\right)$} & SF & $\mathrm{X}$ & $\mathrm{X}$ & $\mathrm{X}$ & $X$ \\
\hline & C & $X$ & $X$ & $X$ & $X$ \\
\hline & $\mathrm{S}$ & $X$ & $X$ & $X$ & $X$ \\
\hline \multirow[t]{3}{*}{ Magnetite $\left(\mathrm{Fe}_{3} \mathrm{O}_{4}\right)$} & SF & $X$ & $X$ & $X$ & $X$ \\
\hline & C & $\mathrm{N} / \mathrm{I}$ & $\mathrm{N} / \mathrm{I}$ & $\mathrm{N} / \mathrm{I}$ & $\mathrm{N} / \mathrm{I}$ \\
\hline & $\mathrm{S}$ & $\mathrm{N} / \mathrm{I}$ & $\mathrm{N} / \mathrm{I}$ & $\mathrm{N} / \mathrm{I}$ & $X$ \\
\hline \multirow{3}{*}{ Quartz $\left(\mathrm{SiO}_{2}\right)$} & SF & $X$ & $X$ & $X$ & $X$ \\
\hline & C & $\mathrm{N} / \mathrm{I}$ & $\mathrm{N} / \mathrm{I}$ & $\mathrm{N} / \mathrm{I}$ & $\mathrm{N} / \mathrm{I}$ \\
\hline & $\mathrm{S}$ & $\mathrm{N} / \mathrm{I}$ & $\mathrm{N} / \mathrm{I}$ & $\mathrm{N} / \mathrm{I}$ & $\mathrm{N} / \mathrm{I}$ \\
\hline \multirow[t]{3}{*}{ Anorthite $\left(\mathrm{Al}_{2} \mathrm{O}_{3} \cdot \mathrm{CaO} \cdot 2 \mathrm{SiO}_{2}\right)$} & SF & $\mathrm{N} / \mathrm{I}$ & $\mathrm{N} / \mathrm{I}$ & $\mathrm{N} / \mathrm{I}$ & $\mathrm{N} / \mathrm{I}$ \\
\hline & $C$ & $\mathrm{~N} / \mathrm{I}$ & $\mathrm{N} / \mathrm{I}$ & $\mathrm{N} / \mathrm{I}$ & $\mathrm{N} / \mathrm{I}$ \\
\hline & $\mathrm{S}$ & $\mathrm{X}$ & $\mathrm{X}$ & $\mathrm{N} / \mathrm{I}$ & $\mathrm{N} / \mathrm{I}$ \\
\hline \multirow[t]{3}{*}{ Gehlenite $\left(\mathrm{Al}_{2} \mathrm{O}_{3} \cdot 2 \mathrm{CaO} \cdot \mathrm{SiO}_{2}\right)$} & SF & $\mathrm{N} / \mathrm{I}$ & $\mathrm{N} / \mathrm{I}$ & $\mathrm{N} / \mathrm{I}$ & $\mathrm{N} / \mathrm{I}$ \\
\hline & C & $\mathrm{N} / \mathrm{I}$ & $\mathrm{N} / \mathrm{I}$ & $\mathrm{N} / \mathrm{I}$ & $\mathrm{N} / \mathrm{I}$ \\
\hline & $S$ & $\mathrm{~N} / \mathrm{I}$ & $X$ & $\mathrm{~N} / \mathrm{I}$ & $\mathrm{N} / \mathrm{I}$ \\
\hline \multirow[t]{3}{*}{ Brownmillerite $\left(\mathrm{CaO} \cdot \mathrm{Fe}_{2} \mathrm{O}_{3}\right)$} & SF & $\mathrm{N} / \mathrm{I}$ & $\mathrm{N} / \mathrm{I}$ & $\mathrm{N} / \mathrm{I}$ & $\mathrm{N} / \mathrm{I}$ \\
\hline & C & $\mathrm{N} / \mathrm{I}$ & $\mathrm{N} / \mathrm{I}$ & $\mathrm{N} / \mathrm{I}$ & $\mathrm{N} / \mathrm{I}$ \\
\hline & $\mathrm{S}$ & $\mathrm{X}$ & $\mathrm{N} / \mathrm{I}$ & $X$ & $X$ \\
\hline
\end{tabular}

Legend: $\mathrm{X}$ - presence; $\mathrm{N} / \mathrm{I}$ - not identified.

$1200{ }^{\circ} \mathrm{C}$; v) ramp of $10^{\circ} \mathrm{C} / \mathrm{min}$ to $1280^{\circ} \mathrm{C}$, isotherm of 2 min at $1280^{\circ} \mathrm{C}$. The two first steps were performed to avoid damaging the ceramic brick on which the sintering bed was deposited. Steps iii-v were based on the results of Hsieh and Whiteman (1989), who reported that the hydration and dehydration of lime $(\mathrm{CaO})$, water vapour condensation, humidity evaporation and coal combustion occur by $700{ }^{\circ} \mathrm{C}$. From 700 to $1280{ }^{\circ} \mathrm{C}$ (steps ii-v), the reactions in the solid and liquid states occur in the sintering bed (Loo and Leung, 2003; Zhang et al., 2012).

\subsubsection{Characterisation of natural, calcined and sintered samples}

2.2.2.1. Chemical characterisation. The chemical compositions of the sinter feed and sinter samples $\left(\mathrm{Fe}_{(\mathrm{T})}, \mathrm{FeO}, \mathrm{SiO}_{2}, \mathrm{Al}_{2} \mathrm{O}_{3}, \mathrm{P}, \mathrm{Mn}\right)$ were determined by inductively coupled plasma optical emission spectrometry (Spectro Agilent, model 725). The FeO and LOI determinations were performed using the gravimetric method. The calcined samples were analysed by X-ray spectrometry (Spectrometer Philips-PANalytical, model MagiX).

2.2.2.2. Mineralogical and textural characterisation. The minerals and crystalline phases in the investigated samples (i.e. sinter feed (SF1, SF2, SF3 and SF4), calcined sinter feed (C1, C2, C3 and C4) and sinter (S1, S2, S3 and S4)) were identified by X-ray diffraction (total powder method). For this purpose, a diffractometer (PANalytical, model Empyrean) equipped with a $\mathrm{Cu}-\mathrm{K} \alpha$ radiation source $(\lambda=1.5405 \AA$ ) was used. The samples were scanned from $2^{\circ} \leq \theta \leq 70^{\circ}$ at an interval of $2^{\circ}$. The database PDF-2/ICDD was used to identify the minerals and crystalline phases in the diffractograms.

Optical microscopy (Leica, model DLP) was used for microtextural analysis of the samples of iron ore and the calcination and sintering products. The semiquantification of mineral phases present in the iron ore sample was performed by point count (Jones, 1987).

The microtextural analysis and the chemical compositions of the phases present in the iron ore sample and in the calcination and sintering products were carried out by scanning electron microscopy (SEM) on a JEOL model JSM 6360 LV equipped with an energydispersive X-ray spectroscopy (EDS) unit (ThermoNORAN model QUEST). For this purpose, the sample sections were previously covered with a thin skin $(20 \mathrm{~nm})$ of Au. The SEM/EDS operations were carried out at voltage of $20 \mathrm{kV}$ and a current of $10 \mathrm{nA}$.

2.2.2.3. Physical characterisation. The densities of samples were determined using a Quantachrome model 1200e ultra pycnometer. The run conditions for the density determinations were as follows: small sample holder, 4 min purge with helium gas at environmental temperature and a target pressure of $127 \mathrm{kPa}$. Four measurements were performed on each sample. The final result was calculated from the average values of three measurements with a standard deviation of $0.005 \%$.

The specific surface area and porosity parameters of samples were measured using a Quantachrome model Nova 1200e surface and porosity analyser. The run conditions for the determinations were as follows: degassing for $17 \mathrm{~h}$ at $195^{\circ} \mathrm{C}$, as previously established by thermal analysis (Silva, 2014); stabilisation time of $180 \mathrm{~s}$. The multipoint BrunauerEmmett-Teller (BET) method was used to determine the specific surface area. The pore size distribution was determined using the Barrett-Joyner-Halenda (BJH) model.

2.2.2.4. Mechanical properties of sinter samples. The mechanical resistances of sintered samples were evaluated using the methodology described by Yang and Loo (1997):

$\mathrm{i}$ - Determination of microhardness by Eq. (001)

$H V=\sum_{i=1}^{i=k}\left[(H V)_{i} *(\% \mathrm{Vol})_{i}\right]$

where, $\mathrm{i}$ is a considered phase, and \% Vol is volume proportion of a considered phase.

ii - Determination of microtumbler (TI) by Eq. (02):

$T I=(0.000231) H V+(0.809)$

The EmcoTest microhardness, model DuraScan 10 was used to determine the Vickers Hardness (HV) of the polished sections of sintered samples. Since the magnetite was not identified in all sintered samples and the calcium silicates occurred in small areas to accommodate the adequate indentation, only the phases hematite and calcium ferrite were considered in HV determination. The strength applied was respectively of 0.1 and $0.3 \mathrm{kgf}$ for hematite and calcium ferrites, determined after preliminary tests, considering the perfect visualisation of the impressions of diagonals. For determination of microhardness of each phase, 10 measurements with $15 \mathrm{~s}$ of indentation were performed. The final microhardness value for each phase was the arithmetic mean of the 10 measurements.

\section{Results and discussion}

\subsection{Chemical characterisation}

Table 2 presents the chemical composition of natural sinter feed (SF), calcined sinter feed (C) and sinter (S). As evident from the results in the table, the $\mathrm{Fe}_{(\mathrm{T})}$ grades of all sinter feed samples were higher than $64 \%$ and the ignition loss (LOI) values varied from 5.5 to $6.1 \%$. These values are mainly related to the high grade of goethite in these samples because the alumina $\left(\mathrm{Al}_{2} \mathrm{O}_{3}\right)$ content normally ascribed to kaolinite is low. The silica $\left(\mathrm{SiO}_{2}\right)$ grades of all analysed samples were below the specification limit of a standard sinter feed (4-6\%), and the phosphorus (P) grades were much higher than standard specifications (maximum 0.07\%) (Lima, 1997).

After the calcination process, a considerable enrichment in Fe content was observed; this enrichment is related to the thermal decomposition of goethite at $320^{\circ} \mathrm{C}$. In their differential thermal analysis of the iron ore sample used in this study, Silva (2014) verified the appearance of an endothermic peak at approximately $320^{\circ} \mathrm{C}$. In addition, very small weight losses for this iron ore sample at temperatures above $700{ }^{\circ} \mathrm{C}$ have also been verified. According to Liu et al. (2012, 2013a, 2013b) 
Table 4

Microtextural composition of sinter feed and sintered samples.

\begin{tabular}{|c|c|c|c|c|c|c|c|c|c|}
\hline Sample & \multicolumn{9}{|c|}{ Microtextural composition (vol.\%) } \\
\hline Sinter feed & $\mathrm{He}_{\mathrm{g}}$ & $\mathrm{He}_{1}$ & $\mathrm{He}_{\mathrm{M}}$ & $\mathrm{He}_{\mathrm{T}}$ & $\mathrm{M}_{\mathrm{g}}$ & $\mathrm{Go}_{\mathrm{b}}$ & $\mathrm{Go}_{\mathrm{e}}$ & $\mathrm{Go}_{\mathrm{T}}$ & $\mathrm{Q}_{z}$ \\
\hline SF1 & 18.3 & 6.0 & 16.3 & 40.6 & 0.03 & 2.6 & 55.6 & 58.2 & 1.1 \\
\hline SF2 & 19.0 & 6.3 & 17.7 & 43.0 & 0.03 & 2.5 & 53.1 & 55.6 & 1.4 \\
\hline SF3 & 26.4 & 6.8 & 16.9 & 50.1 & 0.05 & 2.1 & 45.5 & 47.6 & 2.2 \\
\hline SF4 & 30.1 & 6.9 & 15.1 & 52.1 & 0.06 & 2.0 & 43.4 & 45.4 & 2.4 \\
\hline Sinter & \multicolumn{2}{|l|}{ Hematite } & \multicolumn{2}{|c|}{ Magnetite } & \multicolumn{2}{|c|}{ Silicates $^{\mathrm{a}}$} & \multicolumn{2}{|l|}{ Ferrites $^{\mathrm{b}}$} & Pores \\
\hline S1 & \multicolumn{2}{|l|}{22.9} & \multicolumn{2}{|l|}{ - } & \multicolumn{2}{|l|}{7.7} & \multicolumn{2}{|l|}{47.1} & 22.3 \\
\hline S2 & \multicolumn{2}{|l|}{33.1} & \multicolumn{2}{|l|}{-} & \multicolumn{2}{|l|}{5.2} & \multicolumn{2}{|l|}{33.8} & 27.9 \\
\hline S3 & \multicolumn{2}{|l|}{24.0} & \multicolumn{2}{|l|}{ - } & \multicolumn{2}{|l|}{-} & \multicolumn{2}{|l|}{40.6} & 35.4 \\
\hline S4 & \multicolumn{2}{|l|}{41.7} & \multicolumn{2}{|l|}{0.6} & \multicolumn{2}{|l|}{1.1} & \multicolumn{2}{|l|}{18.9} & 37.7 \\
\hline
\end{tabular}

$\mathrm{He}_{\mathrm{g}}$ - granular hematite; $\mathrm{He}_{1}$ - lamellar hematite; $\mathrm{He}_{\mathrm{M}}$ - martitic hematite; $\mathrm{He}_{\mathrm{T}}$ - total hematite; $\mathrm{Mg}$ - magnetite; $\mathrm{Q}_{\mathrm{z}}$ - quartz $\mathrm{Go}_{\mathrm{b}}$ - botryoidal goethite; $\mathrm{Go}_{\mathrm{e}}$ - earthy goethite; $\mathrm{Go}_{\mathrm{T}}-$ total goethite.

$\mathrm{He}_{\mathrm{T}}=\mathrm{He}_{\mathrm{g}}+\mathrm{He}_{1}+\mathrm{He}_{\mathrm{M}} \cdot \mathrm{Go}_{\mathrm{T}}=\mathrm{Go}_{\mathrm{b}}+\mathrm{Go}_{\mathrm{e}}$

System $\mathrm{Al}_{2} \mathrm{O}_{3} \cdot \mathrm{CaO} \cdot \mathrm{SiO}_{2}$

b System $\mathrm{CaO} \cdot \mathrm{Fe}_{2} \mathrm{O}_{3}$.

and Chen (2013), the dehydroxylation of goethite occurs at approximately $300{ }^{\circ} \mathrm{C}$

The $\mathrm{FeO}$ contents after the sintering process $(0.38 \%$ to $0.93 \%)$ were higher compared to those of the sinter feed samples (0.2\%) (Table 2 ). This result can likely be ascribed to the partial reduction of hematite to magnetite (via solid-state reaction) or formation of magnesiowustite in the presence of a liquid phase at temperatures above $1050{ }^{\circ} \mathrm{C}$ (Kalenga and Garbers-Craig, 2010). Magnetite was not identified in calcined products (Table 3 ) due to its very low concentration.

The average chemical composition of commercialised Brazilian sinters are as follows (Silva, 2014): $\mathrm{Fe}_{(\mathrm{T})}$ : 62.0-57.0\%; FeO: 5.6-7.4\%; CaO: 9.99-10.6\%; $\mathrm{SiO}_{2}$ : 5.60-5.77\%; $\mathrm{Al}_{2} \mathrm{O}_{3}$ : 0.94-1.49\%; $\mathrm{P}$ : 0.050-0.064\%; Mn: 0.38-0.61\%; MgO: 1.25-1.41\%). As evident in Table 2, the chemical 'quality' of sinters produced under the experimental conditions were superior, with the exceptions of the $\mathrm{FeO}, \mathrm{CaO}$ and $\mathrm{P}$ grades, to current Brazilian sinters produced using iron ores with low goethite content. However, metallurgical properties such as tumble index, reducibility, have to be performed with sintered samples of this material from large scale.

\subsection{Mineralogical and textural characterisation}

\subsubsection{X-ray diffraction}

Table 3 presents the main phases identified in the studied natural sinter feed (SF), calcined (C) and sinter (S) samples produced under the experimental conditions. Only the hematite and goethite were identified in the SF samples, likely because of the very small proportions of other mineral phases (quartz, magnetite, kaolinite, gibbsite and talc) identified by Silva (2014) in the fraction size $-0.037 \mathrm{~mm}$ of this iron ore. All of the calcined samples contained only hematite in their mineralogical composition, which is ascribed to the thermal decomposition at approximately $320{ }^{\circ} \mathrm{C}$ of goethite present in SF (Silva, 2014; Leonel,

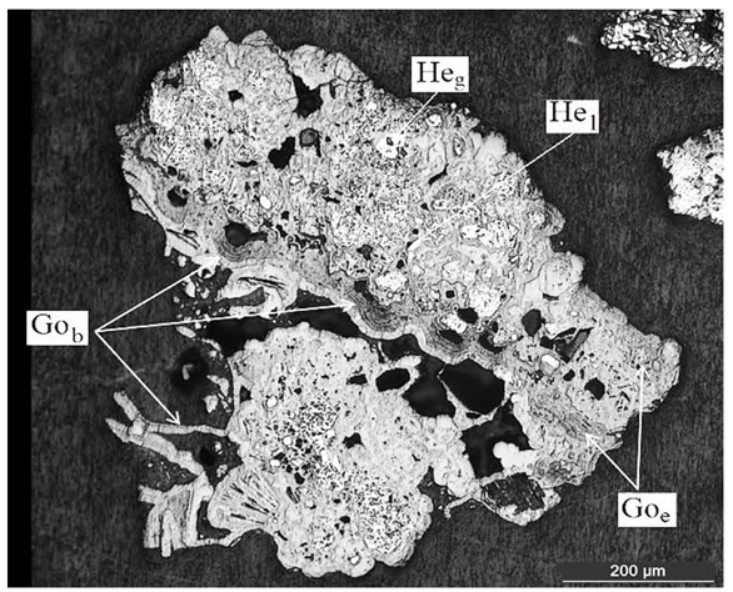

(a)

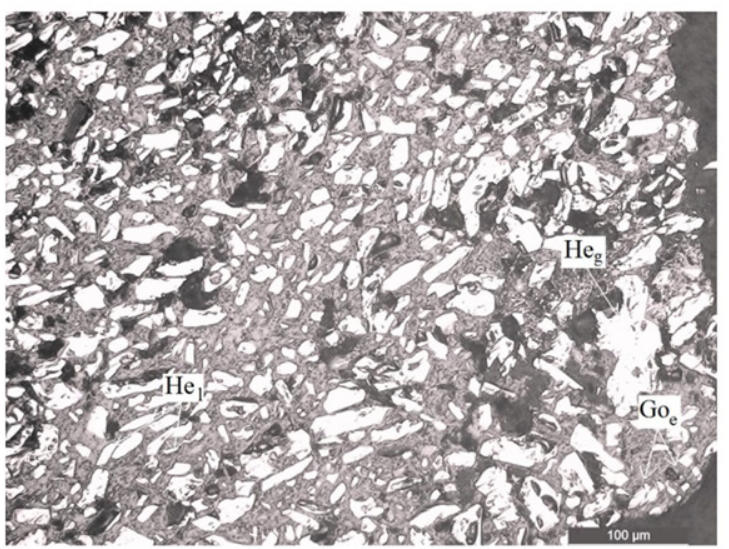

(c)

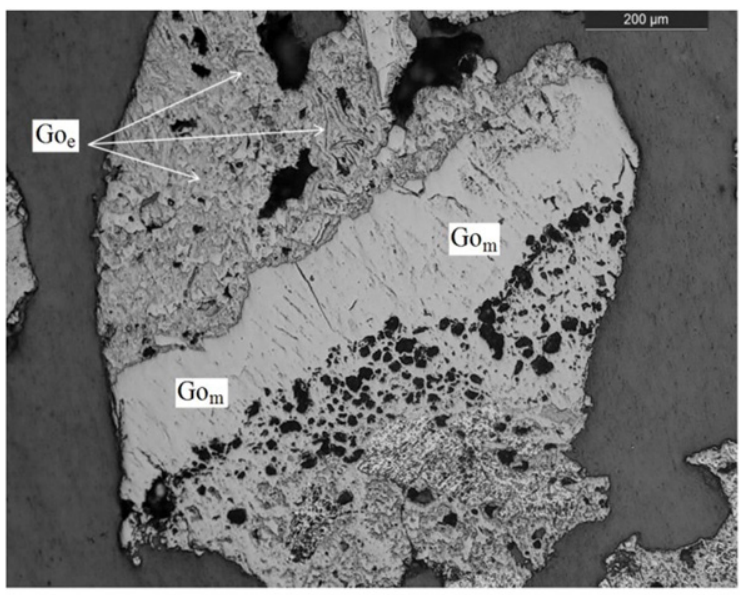

(b)

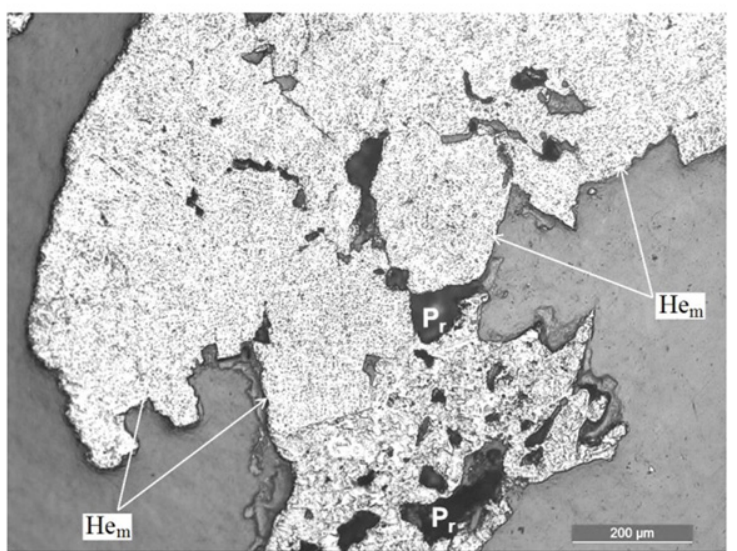

(d)

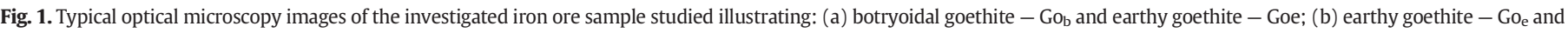

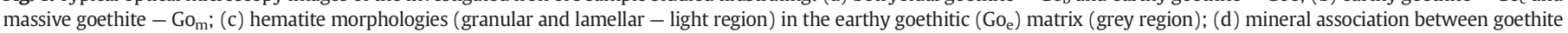
and hematite martitic $-\mathrm{He}_{\mathrm{M}}$ (light region). Note: $\mathrm{P}_{\mathrm{r}}$ - pore. 


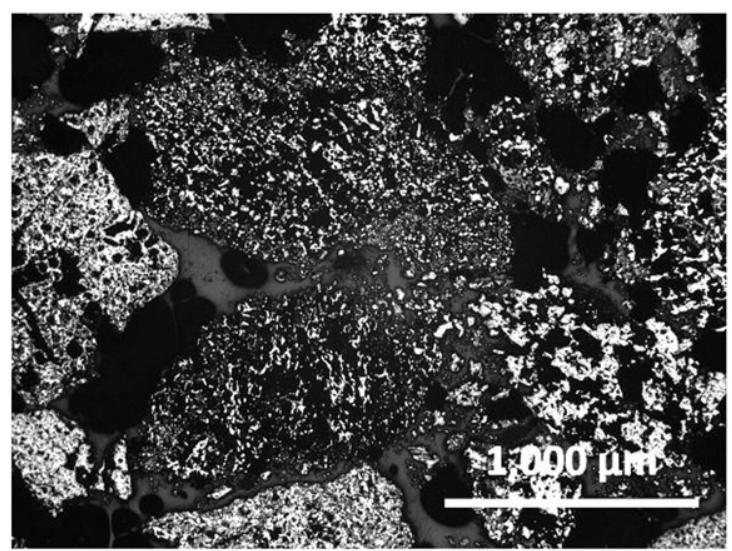

(a)

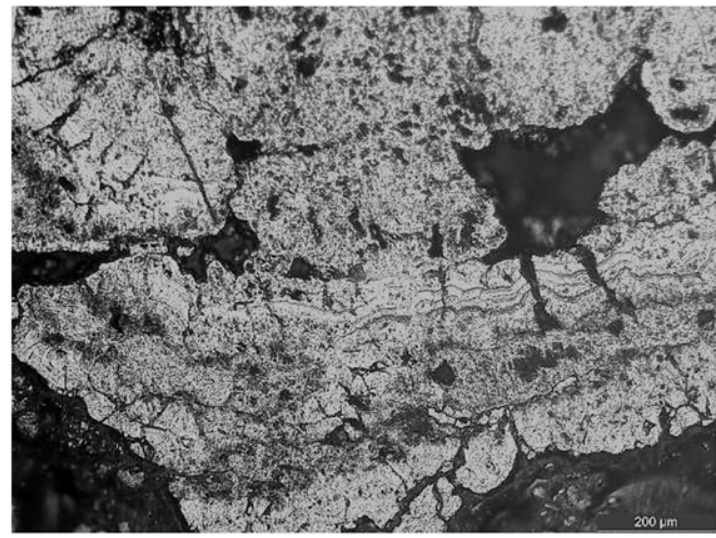

(c)

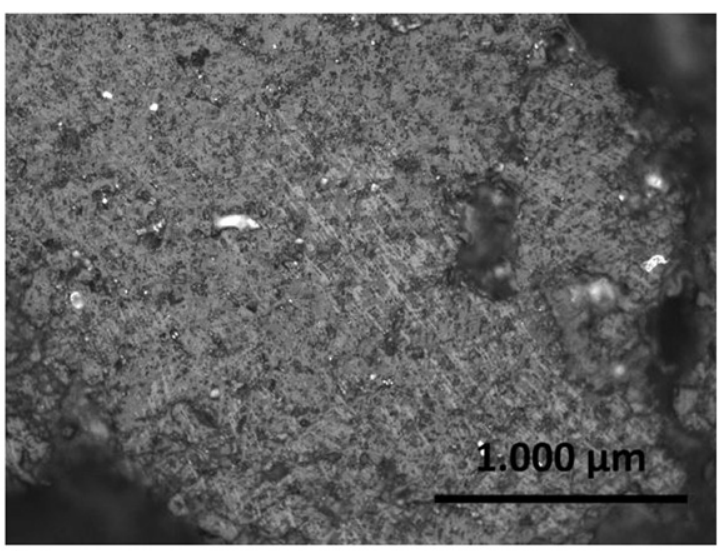

(b)

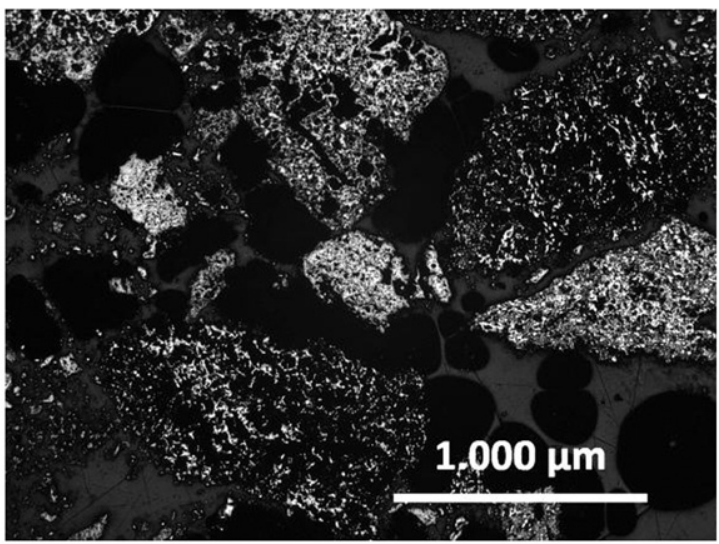

(d)

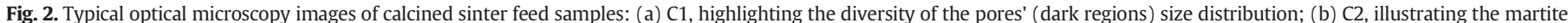
occurrence; (a) C3, showing the hematite with the same microtextural characteristic originating from goethite botryoidal; (b) C4, highlighting the majority presence of the hematite.

2011; Liu et al., 2012, 2013a, 2013b; Chen, 2013). Hematite was identified in all of the sinter samples; however, magnetite was identified only in sinter sample S4. The calcium silicates (identified as anorthite and gehlenite) were observed in sinter samples S1 and S2. Calcium ferrites (identified as brownmillerite, in accordance with Webster et al. (2013)) were observed in all sinter samples except sinter sample S2.

\subsubsection{Optical microscopy}

Table 4 present the semi-quantitative mineralogical and microtextural compositions of sinter feed and sintered products, performed by optical microscopy. Magnetite was identified only in S4, which is coherent with XRD data presented before. Probably, it is due to the higher proportion of adherent particles, which have higher proportion of magnetite as reported by Silva (2014). The main minerals in the studied iron ore sample, as identified and semi-quantified by optical microscopy, were goethite (48.8 wt.\%) and hematite (50.1 wt.\%). The typical microtextural aspects of this sample are shown in Fig. 1. The goethite occurs in massive, earthy and botryoidal forms (Figs. 1a and $1 \mathrm{~b}$ ). The hematite occurs as granular, lamellar and martite microtextures (Fig. 1c). High porosity (dark regions in images) and frequent association between goethite and martite were observed in this ore (Fig. 1d).

As evident in images of the calcination products presented in Fig. 2, the products were highly porous, which is related to the porosity increase due to goethite's thermal decomposition to hematite (Fig. 2a). The micropores in the martite were converted into mesopores through coalescence. In addition, the hematite preserved the original texture of goethite (Figs. 2c). These images confirm that hematite was the majority phase in the calcination products, consistent with the X-ray diffraction results (Table 3 ).

Fig. 3 presents optical microscopy images of the sinter products. Fig. 3a shows the main phases in sinter sample S1: secondary hematite and calcium ferrites. The crystals of hematite exhibit a subeuedric morphology, reflecting its irregular contacts. The calcium ferrites constitute the matrix, and the calcium ferrite crystals also exhibit subeuedric morphology. The pores exhibit diverse sizes and forms.

The main microstructural aspect observed in sinter sample S2 (Fig. 3b) was the presence of the eutectic constituent. This constituent in iron ore sinters is defined as a structure of the $\mathrm{CaO} \cdot \mathrm{SiO}_{2} \cdot \mathrm{Fe}_{2} \mathrm{O}_{3}$ system that is formed by the liquid decomposing into two solids at temperatures lower than $1300{ }^{\circ} \mathrm{C}$ during the cooling step, where the approximate chemical composition of the liquid is $20 \mathrm{wt} . \% \mathrm{CaO}, 35 \mathrm{wt} . \% \mathrm{SiO}_{2}$ and 45 wt.\% $\mathrm{Fe}_{2} \mathrm{O}_{3}$ (Inazumi, 1975; Kasai and Saito, 1996; Kasai et al., 2000; Nyembwe, 2011). In addition, in the case of sinter sample S2, small crystals of calcium silicates were observed near the pores, as also observed by Magalhães et al. (2007).

The phases present in sinter sample S3 (Fig. 3c) and its microstructural aspects were identical to those observed in sinter sample S1: calcium ferrites and hematite in a highly porous matrix. Fig. 3d shows crystals of calcium silicates inside the pores of sinter sample S4. These crystals can be detrimental to the mechanical and metallurgical properties of the sinter because the calcium silicates are poorly reducible brittle phases (Loo and Bristow, 1994). 


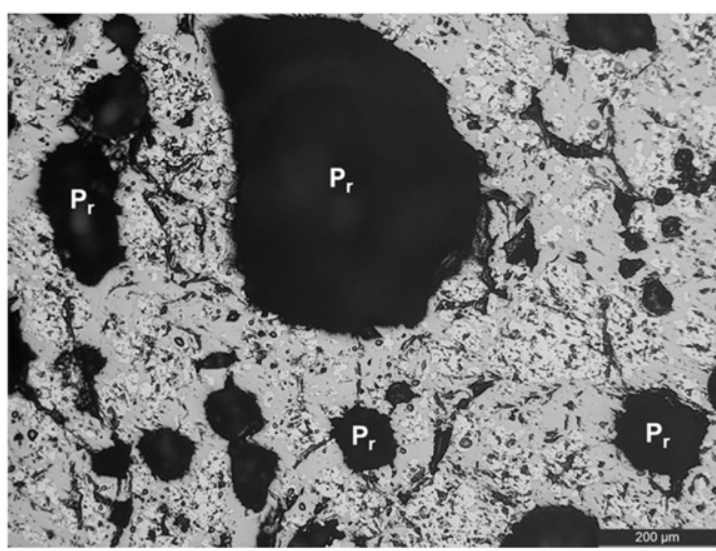

(a)

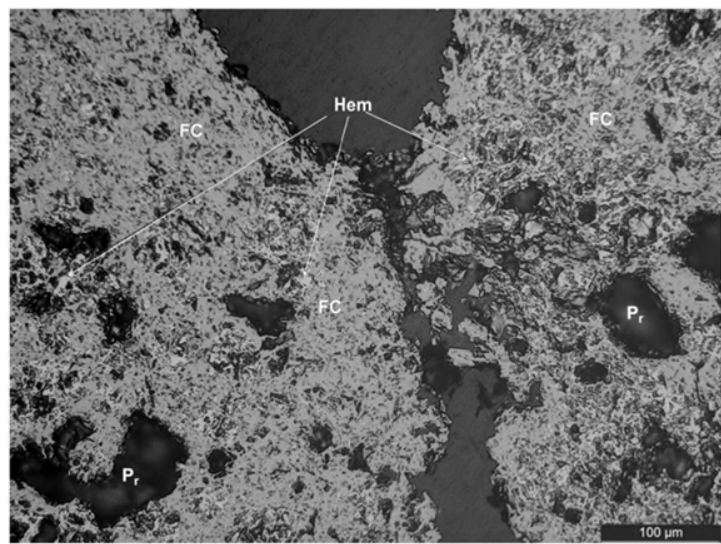

(c)

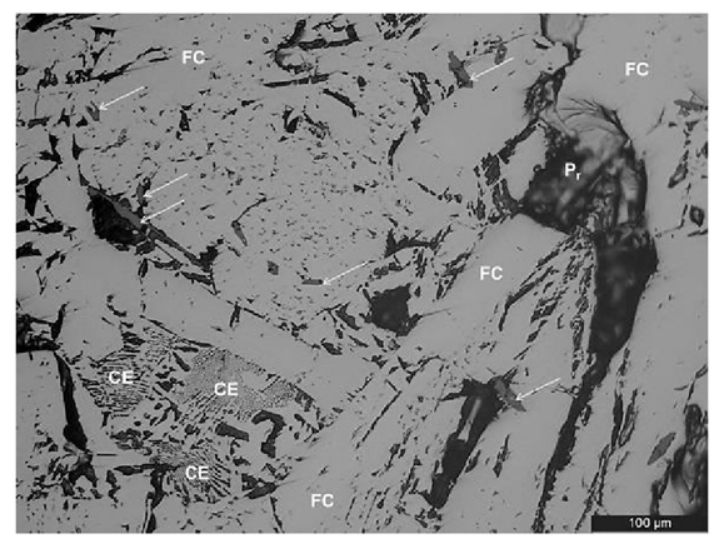

(b)

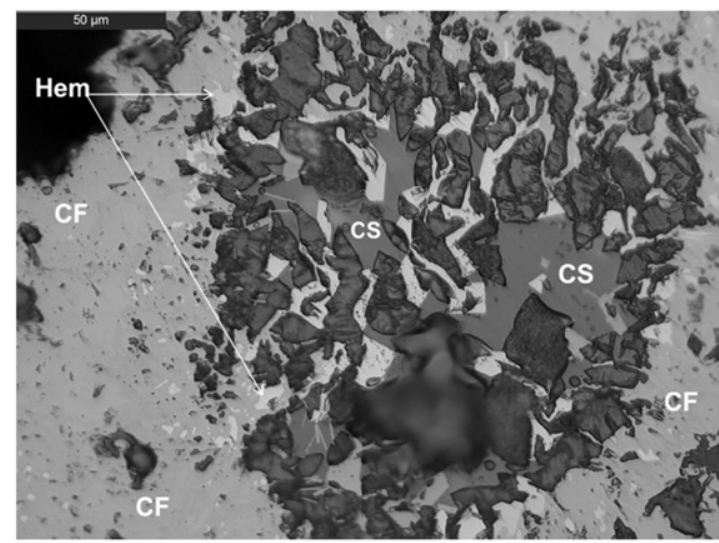

(d)

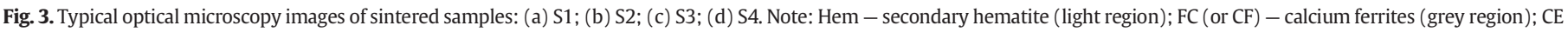

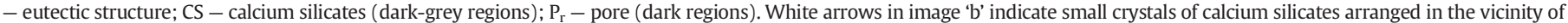
pores.

In general, we observed no correspondence among sintering mixture compositions (proportion and particle type in the sinter feed sample) and the mineralogical composition of the obtained sinter samples. This lack of correspondence is likely related to the fact that the intermediate particles (1.182-0.209 mm) in the sinter feed sample did not exhibit well-defined behaviour. These intermediate particles sometimes promoted a balance between hematite and calcium ferrites, as observed in sinter sample S2 (33\% v/v average for both phases). In other cases, they promoted the formation of calcium ferrites, such as in the case of sinter sample S3 (41\% $v / v$ calcium ferrite and $24 \% v / v$ of hematite). See Table 4.

An increase in the proportion of adherent particles $(-0.209 \mathrm{~mm})$ in the sinter feed sample promoted an increase in porosity in the sinter samples. Sinter sample S4 exhibited the highest porosity value $(38 \% \mathrm{v} /$ $\mathrm{v})$ and the highest proportion of hematite $(42 \% \mathrm{v} / \mathrm{v})$. Therefore, both the mineralogy of the iron ore sample and its previous calcination strongly influenced the sinter structure, consistent with the results of Kimura and Murao (2013) and Webster et al. (2013).

\subsubsection{Scanning electronic microscopy with energy-dispersive X-ray spec-} troscopy (SEM/EDS)

A backscattered electron (BSE) image of a particle of the studied iron ore, which is constituted basically by goethite, is presented in Fig. 4a. Fig. $4 \mathrm{~b}$ presents the region $\mathrm{R} 1$ of this particle, where the chemical analysis was performed by EDS. As evident in Fig. 4a, high $\mathrm{P}_{2} \mathrm{O}_{5}$ levels $(0.88$ to $1.92 \%$ ) are present in all of the analysed points in region $\mathrm{R} 1$. The $\mathrm{Al}_{2} \mathrm{O}_{3}$ grades in earthy goethite (points 1 and 4 ) are higher than in massive and botryoidal goethite, where the $\mathrm{SiO}_{2}$ grades (points 1 and 3 ) were higher than in earthy goethite.

Fig. 5 presents the BSE image of a goethite-martite mineral association. As evident in the figure, the particle has an external surface with high rugosity. The EDS analysis revealed the presence of $\mathrm{Al}_{2} \mathrm{O}_{3}$ in martite, which might stem from the isomorphic substitution of $\mathrm{Fe}^{3+}$ by $\mathrm{Al}^{3+}$ in its crystalline structure. $\mathrm{P}_{2} \mathrm{O}_{5}$ and $\mathrm{SiO}_{2}$ were identified in goethite (point 1 ).

Fig. 6 presents a BSE image of a typical martite crystal and its EDS chemical composition (points 1, 2 and 3), which have a high $\mathrm{Fe}_{2} \mathrm{O}_{3}$ grade (>94.97\%). Figs. 7, 8 and 9 present typical BSE images of sinter samples. On the basis of the chemical composition (EDS) of the points in these images, hematite, calcium ferrites and calcium silicates were identified. The calcium ferrites and calcium silicates phases were previously identified in X-ray diffractograms of the sinter samples as brownmillerite, anorthite and gehlenite, respectively. All of the sinter particles have subeuedric crystals and high porosity.

EDS analysis of the sinter samples revealed that $\mathrm{P}_{2} \mathrm{O}_{5}$ was present in calcium silicate sites (Fig. 8 - point 1 ). This result is consistent with the value reported by Magalhães et al. (2007). However, the higher proportion of $\mathrm{P}_{2} \mathrm{O}_{5}$ (23.8 to $27.11 \%$ ) and $\mathrm{CaO}(45.4$ to $47.13 \%$ ) can be ascribed to apatite (Fig. 7), which was not identified in any sinter feed sample (optical microscopy and XRD) due its low proportion in those samples. 


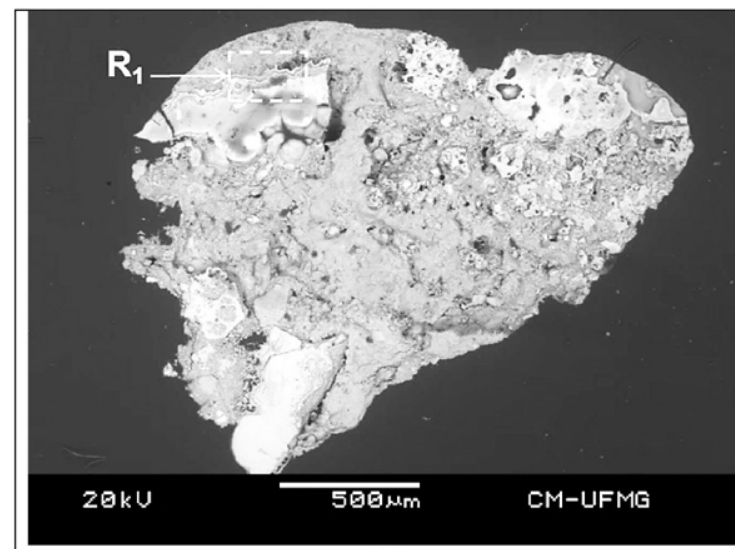

(a)

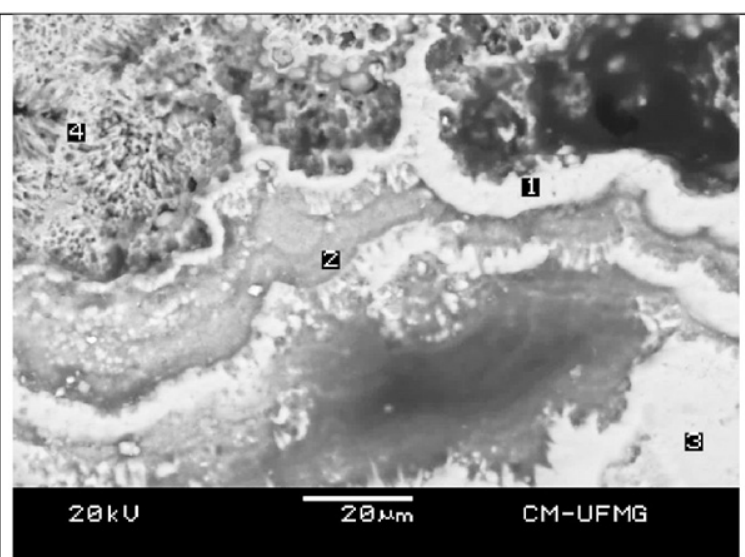

(b)

\begin{tabular}{|c|c|c|c|c|}
\hline \multirow[t]{2}{*}{ Point } & \multicolumn{4}{|c|}{ Chemical composition (wt-\%) } \\
\hline & $\mathrm{Al}_{2} \mathrm{O}_{3}$ & $\mathrm{SiO}_{2}$ & $\mathrm{P}_{2} \mathrm{O}_{5}$ & $\mathrm{Fe}_{2} \mathrm{O}_{3}$ \\
\hline 1 & 1.28 & 4.52 & 1.92 & 92.28 \\
\hline 2 & 2.39 & 3.16 & 0.88 & 93.57 \\
\hline 3 & 1.29 & 3.95 & 1.83 & 92.94 \\
\hline 4 & 2.35 & 2.48 & 1.49 & 93.68 \\
\hline
\end{tabular}

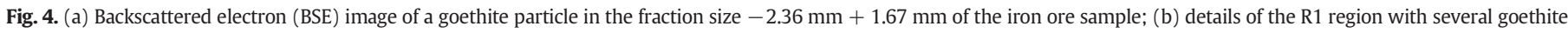

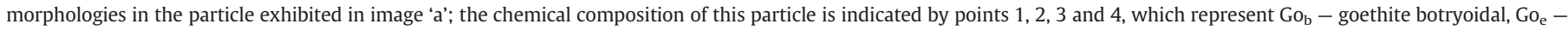
goethite earthy, $\mathrm{Go}_{\mathrm{m}}$ - goethite massive and $\mathrm{Go}_{\mathrm{e}}$ - goethite earthy, respectively.

The CaO grade of the eutectic constituent in sinter sample S2 was approximately $21 \%$ (Fig. 8 ), which is in accordance with the CaO content of the sinter sample reported by Kasai and Saito (1996).

Fig. 9 shows a quartz particle in sinter sample S3; the quartz particles do not react during the sintering process. As evident in the EDS analysis results, a balance exists between the Ca and Si levels in the calcium silicate chemical composition.

\subsection{Physical characterisation}

Table 5 summarises the physical properties of the natural sinter feed (SF), calcined sinter feed (C) and sinter (S) samples. The densities of the SF samples slightly increased from SF1 to SF4; this increase is likely related to the lower LOI levels in the sinter feed samples. After the calcination process, the densities were approximately constant at $4.90 \mathrm{~g} / \mathrm{cm}^{3}$.

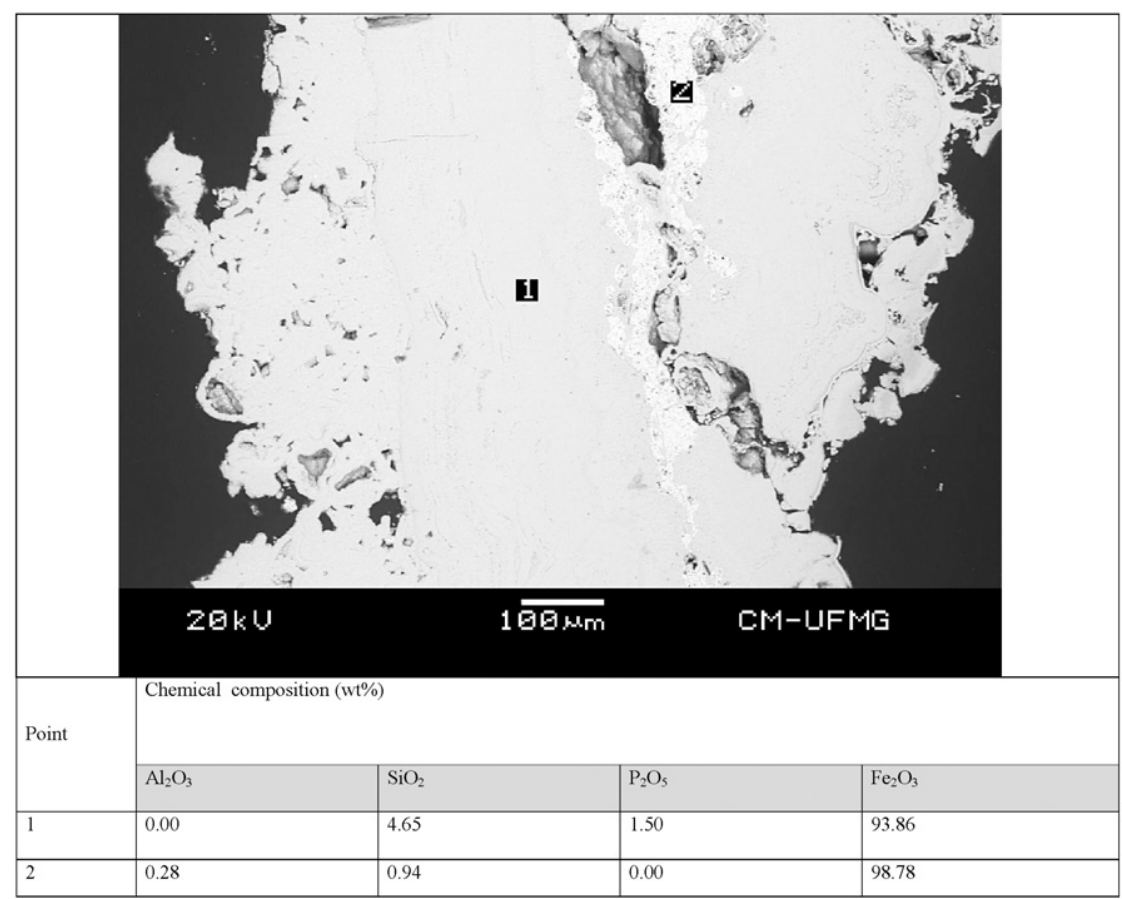

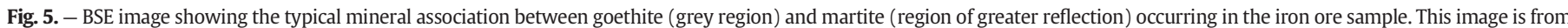
fraction size $-2.36 \mathrm{~mm}+1.67 \mathrm{~mm}$, and the indicated points 1 and 2 show the chemical composition of the goethite massive and martite, respectively. 


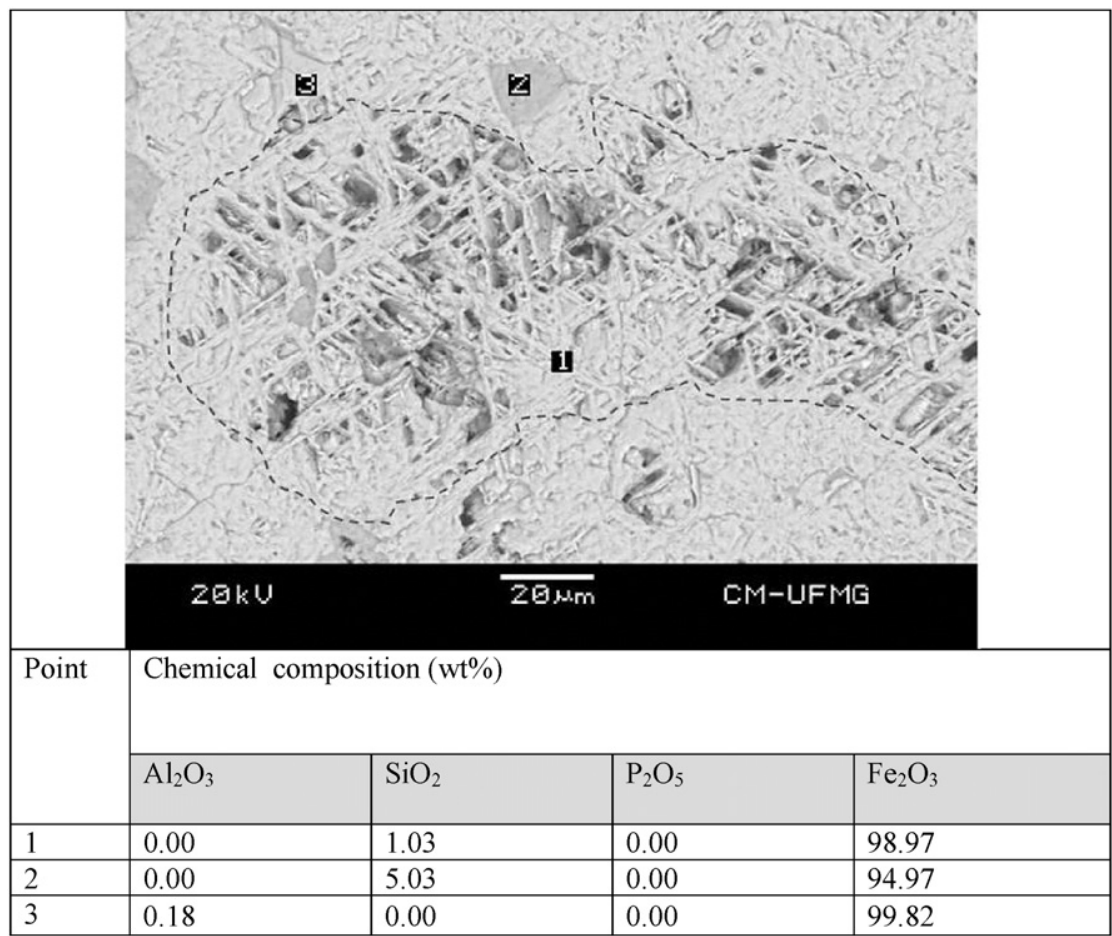

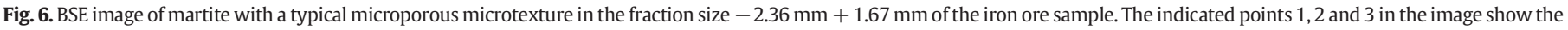
chemical composition of this mineral phase.

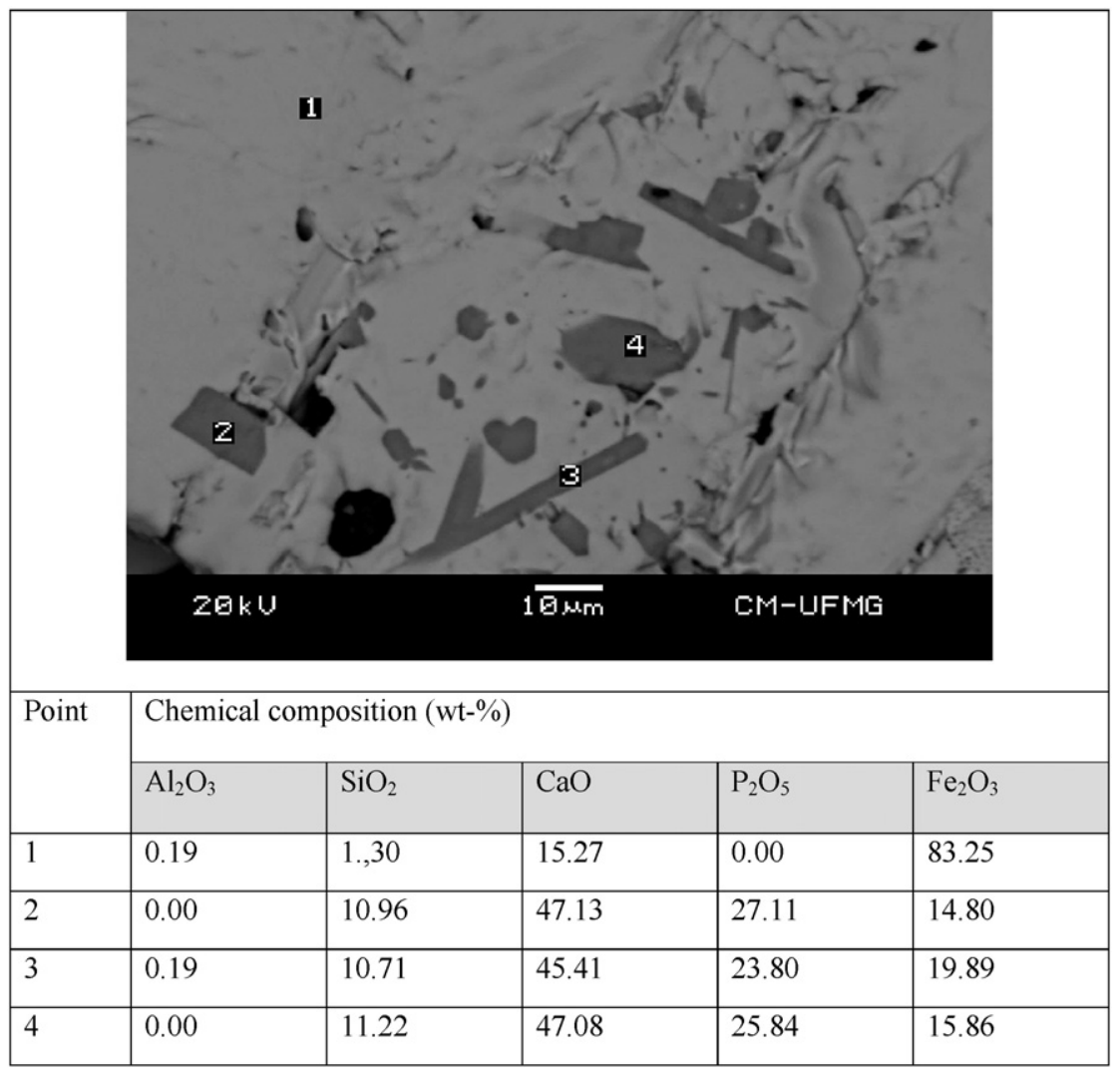

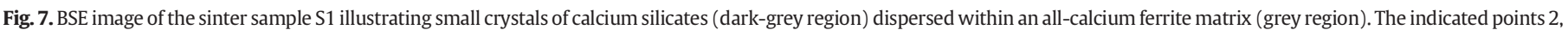
3 and 4 show the chemical composition of apatite. The point 1 shows the chemical composition of calcium ferrite. 


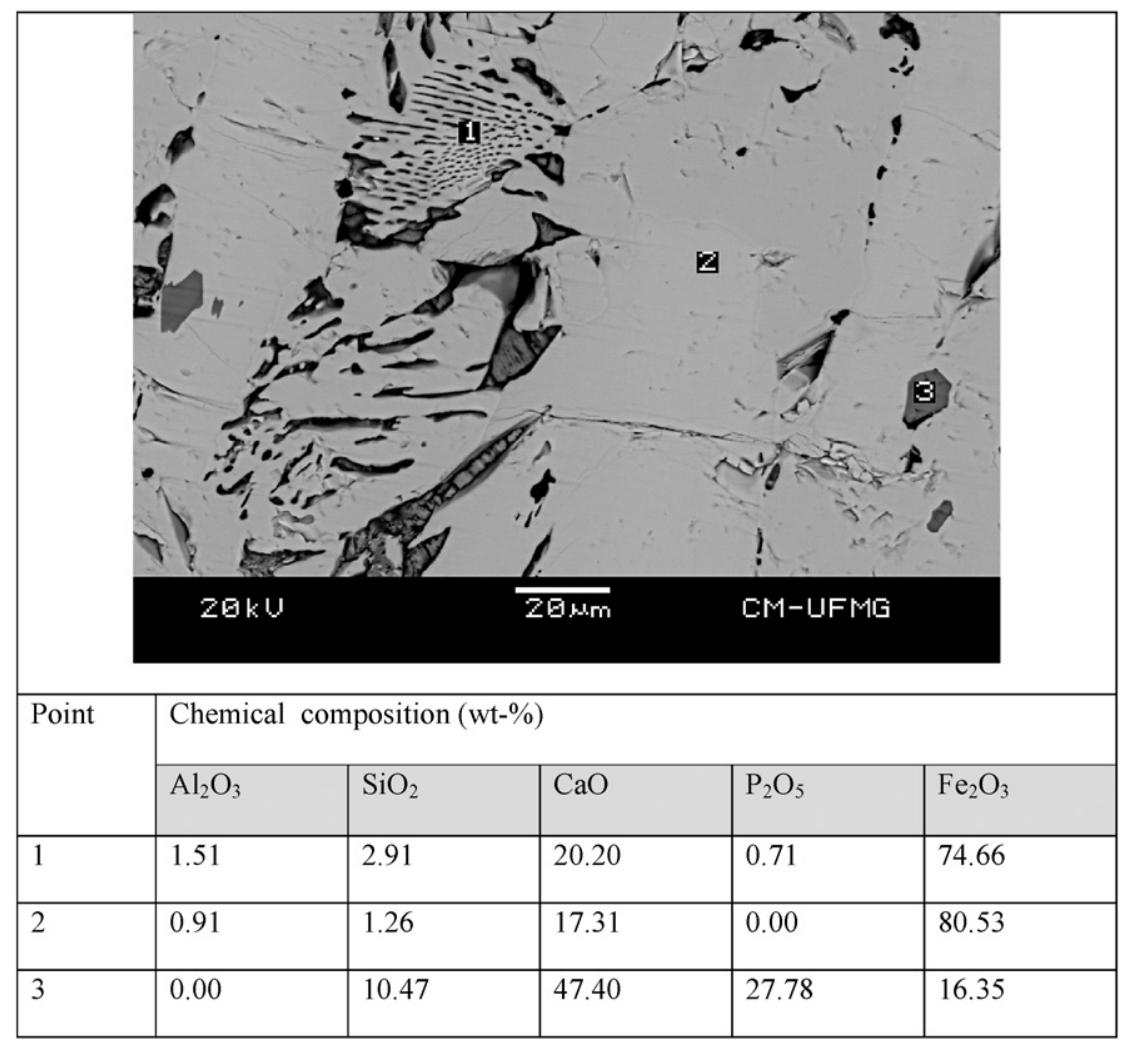

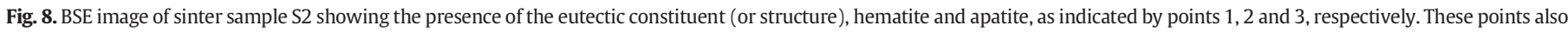
represent the chemical compositions of the mineral phases determined by EDS analysis.

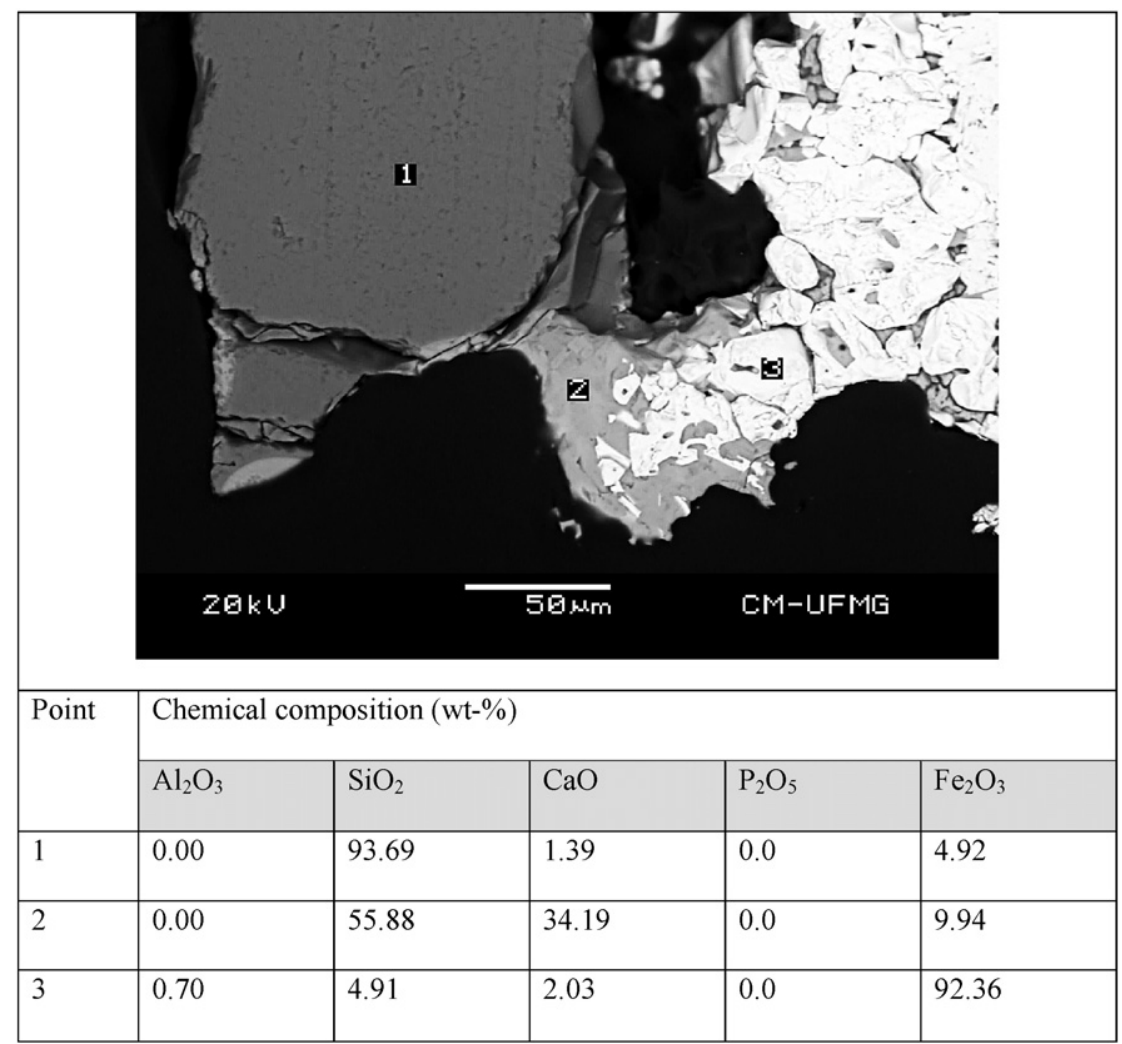

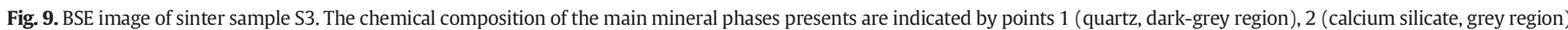
and 3 (hematite, region of greater reflection). 
Table 5

Physical properties of the studied samples: natural sinter feed (SF), calcined sinter feed (C) and sinter (S).

\begin{tabular}{|c|c|c|c|c|c|}
\hline \multirow[t]{3}{*}{ Physical property } & \multicolumn{5}{|c|}{ Sample } \\
\hline & \multirow[t]{2}{*}{ Type } & \multicolumn{4}{|c|}{ Condition } \\
\hline & & 1 & 2 & 3 & 4 \\
\hline \multirow[t]{3}{*}{ Apparent density $\left(\mathrm{g} / \mathrm{cm}^{3}\right)$} & SF & 4.47 & 4.51 & 4.59 & 4.65 \\
\hline & $\mathrm{C}$ & 4.90 & 4.88 & 4.90 & 4.92 \\
\hline & $\mathrm{S}$ & 4.79 & 4.74 & 4.65 & 4.58 \\
\hline \multirow[t]{3}{*}{ Specific surface area $\left(\mathrm{m}^{2} / \mathrm{g}\right)$} & SF & 11.30 & 10.79 & 12.51 & 10.78 \\
\hline & $\mathrm{C}$ & 17.92 & 17.81 & 17.56 & 16.61 \\
\hline & $\mathrm{S}$ & 1.54 & 1.22 & 1.35 & 0.433 \\
\hline \multirow[t]{3}{*}{ Specific pore volume $\left(\mathrm{cm}^{3} / \mathrm{g}\right)$} & SF & 0.0094 & 0.0114 & 0.0141 & 0.0150 \\
\hline & $\mathrm{C}$ & 0.0369 & 0.0368 & 0.0369 & 0.0335 \\
\hline & $\mathrm{S}$ & 0.0037 & 0.0037 & 0.0021 & 0.0013 \\
\hline \multirow[t]{3}{*}{ Pore diameter $(\AA)$} & SF & 37.88 & 37.97 & 38.19 & 37.75 \\
\hline & $C$ & 34.16 & 34.06 & 34.19 & 34.13 \\
\hline & $S$ & 36.91 & 37.22 & 33.43 & 33.79 \\
\hline
\end{tabular}

The thermal decomposition of the goethite to hematite in the calcination step (Table 2 ) resulted in a significant increase in the specific surface area and specific pore volume. This behaviour is consistent with the results of the studies reported by Naono et al. (1987), Weissenborn et al. (1994), Zhang et al. (2010) and Liu et al. (2013a, 2013b).

The specific surface areas of the sinter samples were smaller than those of the calcination products. This result is related to pore structure destruction by the sintering process (Nampi et al., 2011; Strezov et al., 2011).

\subsection{Mechanical properties of sinter samples}

Table 6 presents the values of microhardness and microtumbler of the sintered samples calculated by equations (01) and (02). As can be observed, the microhardness of S1 (70\% nucleating particles/30\% adherent particles) increased from $639 \mathrm{HV}$ to $647 \mathrm{HV}$ in S4 (30\% nucleating particles/70\% adherent particles). The substitution of $15 \%$ of nucleating particles by intermediate particles (S2) resulted in decreasing of microhardness. Opposite behaviour happened when $15 \%$ of adherent particles were replaced by intermediate particles (S3).

The results of microhardness for hematite and calcium ferrites determined in this work are coherent with the values determined by Sinha and Ramma (2009): hematite (525-1246 HV) and calcium ferrite (454 HV-974 HV). It was verified the small reproducibility of microhardness values determined. In accordance with Bristow and Loo (1992) the small reproducibility of the microhardness determinations of sintered samples in bench scale can be ascribed to the irregularity measurements of cracks, which are associated to the residual inside stresses.

The microtumbler of sintered samples varied from $94.8 \%(\mathrm{~S} 2)$ to $98.1 \%$ (S3). No relationship between the proportions of nucleate, intermediate and agglomerate particles used in mixture of sinter tests with the results of microtumbler calculated from Eq. (02) was identified.

Table 6

Microhardness and microtumbler of sintered samples.

\begin{tabular}{lllll}
\hline \multirow{2}{*}{ Sample } & \multicolumn{2}{l}{ Microhardness (HV) } & \multirow{2}{*}{ Microtumbler (\%) } \\
\cline { 2 - 4 } & Hematite & Calcium ferrite & Agglomerate & \\
\hline S1 & $853 \pm 339$ & $535 \pm 168$ & 639 & 95.7 \\
S2 & $794 \pm 125$ & $412 \pm 157$ & 601 & 94.8 \\
S3 & $977 \pm 213$ & $605 \pm 121$ & 743 & 98.1 \\
S4 & $699 \pm 160$ & $598 \pm 247$ & 647 & 95.8 \\
\hline
\end{tabular}

\section{Conclusions}

On the basis of studies of bench-scale calcination followed by a sintering step conducted with an iron ore with a high grade of goethite, we concluded that all of the sinter feed samples exhibited an Fe grade greater than $64 \%$ and a very high $P$ grade $(\sim 0.17 \%)$. After the calcination process, an enrichment of 3.1-3.4\% of the Fe grade was observed because of the thermal decomposition of goethite to hematite, which involves the loss goethite's hydroxyl group. The sinter samples exhibited an average Fe grade of 59.1\%. The main mineral phases in the iron ore sample were goethite and hematite. In the calcined samples, only hematite was identified because of the thermal decomposition of goethite at $320^{\circ} \mathrm{C}$. In the sinter samples, hematite, calcium ferrite (brownmillerite) and calcium silicate (anorthite and gehlenite) were identified. The sites for phosphorus occurrence were calcium silicates and apatite (an average of $26.1 \%$ by EDS analysis). Increases were observed in the specific surface area, specific pore volume and pore diameter of the calcined samples compared to those of the raw materials. The lowest values of specific surface area observed in the sinter samples $\left(0.43-1.54 \mathrm{~m}^{2} / \mathrm{g}\right)$ compared to the calcined samples $\left(16.6-17.9 \mathrm{~m}^{2} / \mathrm{g}\right.$ ) are likely related to the destruction of the pore structure by the sintering process. No relationship between the proportions of nucleating, intermediate and agglomerate particles used in mixture of sinter tests with the results of microtumbler was identified.

\section{Acknowledgements}

The authors gratefully acknowledge the financial support by Fapemig and PROPP/UFOP, CAPES, CNPq through scholarships for two authors and Vale S.A by providing the iron ore sample.

\section{References}

MI, Al-Wakeelm, El-Rahman, M.K., 2006. Beneficiation of low grade Ghorabi iron ore, Bahariya Oasis, Egypt: a case study. Min. Proc. Ext. Metall. (Trans. Inst. Mineral Metall. C) $115(4), 177-182$

Araujo, A.C., Amarante, S.C., Souza, C.C., Silva, R.R.R., 2003. Ore mineralogy and its relevance for selection of concentration methods in processing of Brazilian iron ores. Min. Proc. Ext. Metall. (Trans. Inst. Mineral Metall. C) 112, C44-C64.

Bristow, N.J., Loo, C.E., 1992. Sintering properties of iron ore mixes containing titanium. ISIJ Int. 32 (7), 819-828.

Carlos, D.U., Uieda, L., Barbosa, V.C.F., 2014. Imaging iron ore from the Quadrilátero Ferrífero (Brazil) using geophysical inversion and drill hole data. Ore Geol. Rev. 61 (2014), 268-285.

Chen, Y., 2013. Thermal properties of nanocrystalline goethite, magnetite, and maghemite. J. Alloys Compd. 553, 194-198.

Hsieh, L.H., Whiteman, J., 1989. Sintering conditions for simulating the formation mineral phases in industrial iron ore sinter. ISIJ Int. 29 (1), 24-32.

Inazumi, T., 1975. Applied Mineralogical Studies on Self-Fluxing Sinter of Iron Ore PhD Thesis Tokyo University, Tokyo, Japan.

Jesus, C.A.G., 2013. Brazilian Mineral Summary. Publishing by National Department for Mineral Research - DNPM site (Accessed 03 May 2014).

Jones, M.P., 1987. Introduction to applied mineralogy. Applied Mineralogy a Quantitative Approach 1. Graham and Trotman Ltd., Oxford-Great Britain, pp. 1-12 259p. Chapter.

Kalenga, M., Garbers-craig, A., 2010. Investigation into how the magnesia, silica, and alumina contents of iron ore sinter influence its mineralogy and properties. J. South. Afr. Inst. Min. Metall. 110, 447-456.

Kasai, E., Saito, F., 1996. Differential thermal analysis of assimilation and melt-formation phenomena in the sintering process of iron ore. ISIJ Int. 36 (8), 1109-1111.

Kasai, E., Sakano, Y., Kawaguchi, T., Nakamura, T., 2000. Influence of properties of fluxing materials on the flow of melt formed in the sintering process. ISIJ Int. 40 (9), 857-862.

Kimura, M., Murao, R., 2013. Continuous Cooling transformation (CCT) Concept for iron Ore sintering using in Situ Quick X-ray diffraction and Confocal Laser Microscope. ISIJ Int. 53 (12), 2047-2055.

Leonel, C., 2011. Calcination Process Study as Unitary Additional Operation on High LOI Level Iron Ore Pelletizing PhD Thesis Federal University of Minas Gerais, Belo Horizonte, Brazil (in Portuguese).

Lima, R.M.F., 1997. Starch and amines adsorption on hematite and quartz surfaces and its influence in flotation PhD Thesis Federal University of Minas Gerais, Belo Horizonte, Brazil (238pp in Portuguese).

Liu, H., Chen, T., Chang, J., Zou, X., Frost, R., 2013a. The effect of hydroxyl groups and surface area of hematite derived from annealing goethite for phosphate removal. J. Colloid Interface Sci. 398, 88-94. 
Liu, H., Chen, T., Xie, Q., Zou, X., Qing, C., Frost, R., 2012. Kinetic study of goethite dehydration and the effect of aluminium substitution on the dehydrate. Thermochim. Acta 545, 20-25.

Liu, H., Chen, T., Zou, X., Qing, C., Frost, R., 2013b. Thermal treatment of natural goethite: thermal transformation and physical properties. Thermochim. Acta 568, 115-121.

Loo, C.E., Bristow, N., 1994. Mechanism of low-temperature reduction degradation of iron ore sinters. Trans. Instn. Min. Metall. (Sect. C: Mineral processing and Extr. Metall.) 103, C126-C134

Loo, C.E., Leung, W., 2003. Factors influencing the bonding phase structure of iron ore sinters. ISIJ Int. 43 (9), 1393-1402.

Loo, C.E., Witchard, D., Penny, G.C., 1994. Improving sintering performance of ore blend containing pisolitic ore. Trans. Instn. Min. Metall. (Sect. C: Mineral processing and Extr. Metall.) 103, C135-C146.

Loo, C.E., 2005. A perspective of goethite ore sintering fundaments. ISIJ Int. 45 (4), 436-448.

Magalhães, M.S., Brandão, P.R., Tavares, R.P., 2007. Types of goethite from Quadrilátero Ferrifero's iron ores and their implications in the sintering process. Trans. Instn. Min. Metall. (IMM Transactions Section C) 116, 54-64.

Mendes, M., Lagoeiro, L., 2012. Microstructures, crystallographic fabric development and deformation mechanisms in natural hematite aggregates deformed under varied metamorphic conditions. Journal of Structural Geology. 40, 29-43.

Nampi, P., Ghosh, S., Warrier, K., 2011. Calcination and associated structural modifications in boehmite and their influence on high temperature densification of alumina. Ceram. Int. 37, 3329-3334.

Naono, H., Nakai, K., Sueyoshi, T., Yagi, H., 1987. Porous texture in hematite derived from goethite: mechanism of thermal decomposition of goethite. J. Colloid Interface Sci. 120 (2), 439-450.

Nyembwe, M., 2011. Study of Sinter Reactions When Fine Ore is Replaced With Coarse Ore, Using an Infrared Furnace and Sinter Pot Tests PhD thesis University of Pretoria, Pretoria, South of Africa.

Okazaki, J., Higuchi, K., Hosotani, Y., Shinagawa, K., 2003. Influence of iron ore characteristics on penetrating behavior of melt into ore layer. ISIJ Int. 43 (9), 1384-1392.

Rosière, C. A. 1996. A model for microstructural evolution of iron ore from Iron Quadrangle. Pat II - trame, texture and anysotropism of magnetic susceptibility. Geonomos, v.4, n.1, pp. 61-75 (in Portuguese).
Sakamoto, N., Niwa, Y., Komatsu, O., Noda, H., Kumasaka, A., 1993. Commercial production of iron ore agglomerates using sinter feeds containing a large amount of fines ores. ISIJ Int. 33 (4), 454-461.

Sakamoto, N., Noda, H., Kawata, H., Ichikawa, K., Sato, H., 1997. A commercial production test of iron ore sinter using high amounts of pisolites ores and quality evaluation of the sinter products. ISIJ Int. 37 (11), 1066-1071.

Silva, M.S.S., 2014. Sintering in Bench Scale of Calcined Goethitic Iron Ore Dissertation Federal University of Ouro Preto, Ouro Preto, Brazil 145 pp. (in Portuguese).

Sinha, M., Ramna, R.V., 2009. Effect of variation of alumina on the microhardness of iron ore sinter phases. ISIJ Int. 49 (5), 719-721.

Strezov, V., Evans, T., Zymla, V., Strezov, L., 2011. Structural deterioration of iron ore particles during thermal processing. Int. J. Miner. Process. 100, 27-32.

Umadevi, T., Brahmacharyulu, A., Roy, A., Mahapatra, P., Prabhu, M. and Ranjan, M. 2011. Influence of Iron Ore Fines Feed Size on Microstructure, Productivity and Quality of Iron Ore Sinter. ISIJ International 51, n. 6, 922-929.

Webster, N., Pownceby, M., Madsen, I., Kimpton, J., 2013. Effect of oxygen partial pressure on the formation mechanisms of complex Ca-rich ferrites. ISIJ Int. 53 (5), 774-781.

Weissenborn, P., Dunn, J., Warren, L., 1994. Quantitative thermogravimetric analysis of haematite, goethite and kaolinite in western Australian iron ores. Thermochim Acta 239, 147-156.

Wolff, A.P., 2009. Characterization of Iron Ore Tailings from Vale's Mines M.Sc. dissertation Federal University of Ouro Preto, Ouro Preto, Brazil 90pp (in Portuguese).

Yang, L.X., Loo, C.E., 1997. Structure of sinters formed from complex chinese iron ores. ISI] Int. 37 (5), 449-457.

Yang, L.X., Witchard, D., Yu, Z.N., 2000. Introduction of pisolitic goethite ore into a Chinese ore blend. ISIJ Int. 40 (7), 647-653.

Zhang, F., An, S., Luo, G., Wang, Y., 2012. Effect of basicity and alumina-silica ratio on formation of silico ferrite of calcium and aluminum. J. Iron Steel Res. Int. 19, 1-5.

Zhang, W.J., Huo, C.F., Feng, G., Li, Y.W., Wang, J., Jiao, H., 2010. Dehydration of goethite to hematite from molecular dynamics simulation. J. Mol. Struct. THEOCHEM 950, 20-26. 